\title{
Declining Food Security in a Philippine Oil Palm Frontier: The Changing Role of Cooperatives
}

\author{
Marvin Joseph F. Montefrio and Wolfram H. Dressler \\ ABSTRACT
}

The long-held redistributive function of agricultural cooperatives — one of moral economy and poverty alleviation - has changed dramatically as they emerge as core brokers for agro-industrial development in the so-called 'green economy'. This article examines the changing role of cooperatives involved in brokering oil palm production and its impact upon the food security and livelihoods of smallholders who labour in plantation regimes situated in historically uneven agrarian political economies. Findings show how, increasingly, cooperatives reinforce uneven agrarian social relations of production and exchange in which indigenous smallholders experience a loss of land, poor wage labour conditions tinged with insecurity and prejudice, and mounting debt in an expanding oil palm complex. The article suggests that these changes in agrarian social relations negatively influence indigenous farmers food security pathways, with their access to and use of appropriate foods diminishing. It asserts that understanding the impacts of cooperatives on food security pathways requires a relational and situated analysis of livelihood change and agrarian relations in extractive frontiers.

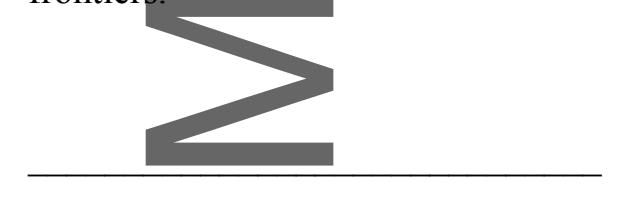

[insert first unnumbered footnote here]

This article entails equal contribution and co-authorship. The authors would like to thank all the households of the Sofronio Española area for their time and availability during this research and the Pala'wan specifically for granting our research Free, Prior and Informed Consent. We also thank Alex Felipe and Ana Bibal for their research assistance and the anonymous referees for their helpful comments. Montefrio's research was supported by the International Development Research Centre (FN 106612-99906060-005) and Yale-NUS College, while Dressler's research was generously supported by the ARC Future Fellowship (FT130100950), the School of Geography, and the Faculty of Science, University of Melbourne.

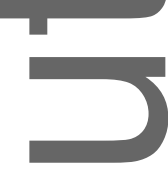

This is th auth r manuscript accepted for publication and has undergone full peer review but has not been througn - copyediting, typesetting, pagination and proofreading process, which may lead to differences between this version and the Version of Record. Please cite this article as doi:

10.1111/dech.12443.

This article is protected by copyright. All rights reserved. 


\section{INTRODUCTION}

Globally, nation states have reinforced long-standing rural development agendas through sustained
investments in agro-industrial expansion to address food security and alleviate poverty. Revitalized
rural modernization ideals now work through the broader policy and practice of so-called 'inclusive growth' and 'green' economic development to integrate smallholder farmers into contract farming and outgrower production of high value commodities for international markets such as palm oil and rubber (McCarthy and Cramb, 2009; Montefrio and Dressler, 2016). Recently, a burgeoning literature has critically examined how the expansive rise of contract farming for agro-industrial production has driven notional land grabbing' and other patterns of inclusion, exclusion and adverse incorporation that reproduce problematic livelihood outcomes for poor farmers (Borras and Franco, 2012, 2013 ; Hall et al., 2011; Li, 2011; McCarthy, 2010). While most of these studies focus on contract farming arrangements and their consequences for the rural poor, much less research has examined how various agents and organizations (such as cooperatives) become implicated and transformed as they broker and mediate land, labour and capital into the production supply chains of agro-industries. In particular, as the role and impacts of agricultural cooperatives and related institutions shift from a redistributive focus to engage greater finance and capital flows to facilitate the expansion of biofuel production, a range of critical questions have emerged concerning their relationship with and impact on farm labour, land and livelihoods as biofuel plantations continue to expand into frontiers (Brass, 2007; McCarthy, 2010).

In this article, we examine the role of cooperatives in mediating access to land, labour and capital in agro-industrial production and consider the broader implications on indigenous livelihoods and food security. What, for example, happens to cooperatives when they serve as central mediators and brokers in the provision of labour and food for boom crop production? What happens to the rural poor upon being incorporated as labourers into cooperative structures for agro-industrial production? How are the rural poor's livelihoods and food security impacted over time? We answer these questions by focusing on the case of cooperatives involved in oil palm production in the Philippines.

The agricultural cooperative movement has a long history in the Philippines. State-recognized rural credit and agricultural cooperatives have existed since the American colonial period in the early 1900s (Ferrer, 1956), but their features, characteristics and the premise of their existence have changed significantly in the last few decades. The movement was slow to emerge in the early post-

This article is protected by copyright. All rights reserved. 
colonial period but gained prominence during the Marcos (1965-86) and Aquino (1986-92) regimes, when cooperatives were eventually recognized in the 1987 Philippine Constitution as 'instruments of equity, social justice and economic development' (Article XII, Section 15). ${ }^{1}$ Guided by Republic Act No. 6938 or the Cooperative Code of the Philippines, ${ }^{2}$ cooperatives are expected to embrace the principles of open and voluntary membership, democratic control, limited interest in capital, division of net surplus and cooperation among members (Sam et al., 2013). Having a 'redistributive' rationale, cooperatives in the Philippines are thus expected to help smallholder farmers surmount production challenges associated with long-standing land uses and commodities (e.g. copra and rice), such as difficulty in accessing information, high-quality inputs and loans (Kumar et al., 2015). In the last two decades, state and non-state actors in the Philippines have invested in such discourse and ideals, upholding cooperatives as 'instrumental institutions' for rural economic development that bridge the perceived 'gap' between smallholders and agri-businesses (through, for example, contract farming) (Manalili, 2003; Nozawa, 2011).

Contrary to their intended redistributive goals, however, many agricultural cooperatives in the
Philippines today have been organized and controlled by government agencies, private companies and local elites to serve particular political and economic interests that underpin boom crop production. They have undergone a fundamental transformation in their thrust from being 'service-oriented' groups that support member needs to more profit-oriented institutions that serve state and private corporations infacilitating the expansion of biofuel production (Dalabajan, 2015; Guinto and Otahara, 1999). In many instances, older and newer agricultural cooperatives emerge with narrower 'marketoriented' functions to facilitate the expansion of commodity crops and ensure that the rural labour underpinning this is managed and controlled in ways to enhance production. When cooperative leaders and members become enmeshed in the intensifying capitalist relations of lucrative boom crop production, associated land, labour and livelihoods are often subject to profoundly uneven social relations of production and exchange (see Brass, 2007; Hairong and Yiyuan, 2013). In this context, then, the transformation of cooperatives toward a more uniform market orientation can contribute to livelihood vulnerability and food insecurity among smallholders in the rural Philippines. Yet in

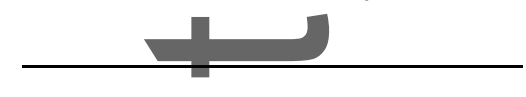

\footnotetext{
${ }^{1}$ For more on the Constitution of the Philippines, see www.officialgazette.gov.ph/constitutions/1987constitution/

${ }^{2}$ For further information on the Cooperative Development Authority of the Philippines, see www.cda.gov.ph/resources/issuances/republic-act-6939
}

This article is protected by copyright. All rights reserved. 
exploring these transformations, we heed Brass (2007) who cautions against dichotomizing the role of agricultural cooperatives as either being 'socialist saviours' of a weak peasantry subject to hegemonic states or businesses, or being wholly 'co-opted' and driven by market logic and capitalist relations. Indeed, rather than working in a uniform, linear and totalizing manner, many cooperatives continue to empathize with the rural poor as they manage structural constraints, financing and entrenched social relations that upland farmers negotiate in various ways.

We focus on Palawan island, in the Philippines, where cooperatives supporting older commodity crops such as copra and irrigated rice have increasingly renegotiated their principles and mandates to accommodate more capital-oriented, agri-business schemes. We argue that this overall shift in objectiyes has important implications for food security among indigenous smallholders who become involvedin cooperative production through long-standing agrarian social relations. In critically examining the links between the changing political economic character of cooperatives and food security, we focus on the case of oil palm-growing cooperatives in southern Palawan. We illustrate how agricultural cooperatives involved in oil palm production have mediated social relations of production and exchange among smallholders and their livelihoods, and how this tendency impacts access to and use of the subsistence foods of indigenous Pala'wan farmers. ${ }^{3}$ Our analysis draws on a critical agrarian studies perspective that attends to the relational and emic-notions of livelihood and food security. We do this by examining the situated character of four aspects of social relations of production and exchange - land, labour, debt and prejudice - and how these articulate with livelihoods, food production and (in)security. We suggest that changes in social relations among smallholders due to the mounting loss of land and control over labour have significantly influenced livelihood trajectories and access to and use of food, with major implications for food security for those who beeome unevenly incorporated into oil palm development and its institutional structures. Rather than demonstrating a 'definitive point' at which food security becomes food insecurity, we examine the emerging pathways in which once relatively self-sufficient indigenous farmers encounter intersections of prejudice, indebtedness and land and labour constraints that make them more vulnerable to food insecurity in the context of agrarian change.

We discuss next the methods and broader trends in the literature on food security and livelihoods, with emphasis on its relational dimensions in critical agrarian studies. We then describe

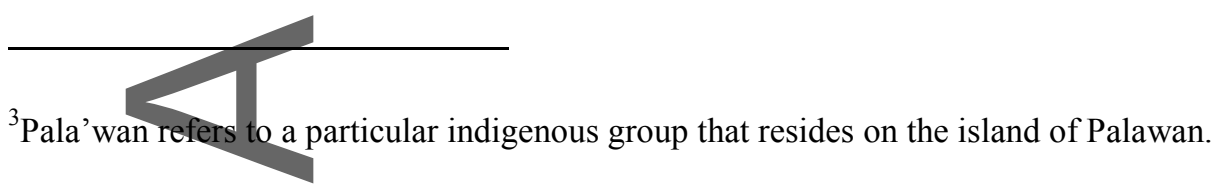

This article is protected by copyright. All rights reserved. 
our study area, and the livelihood and food security profile of the indigenous Pala'wan smallholders we investigated. Finally, we examine a detailed case study of how cooperatives mediate social relations, livelihoods and food security among Pala'wan smallholders who are being incorporated into the oil palm production regime.

\section{METHODOLOGY}

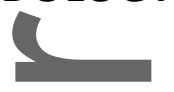

This article is based on ethnographic research in an oil palm-growing municipality in southern Palawan conducted over several months in 2012, 2015 and 2016. We focus on two cases of oil palmgrowing cooperatives (the Mingas and the Biluan Multi-Purpose Cooperatives, hereafter 'Mingas' and 'Biluan') spanning two barangays ${ }^{4}$ in the municipality of Sofronio Española, southern Palawan (see Figure 1). Both cooperatives have maintained some of the largest oil palm production areas in Palawan, and have been involved in the allocation/management of labour and the provisioning of foodstuffs and credit.
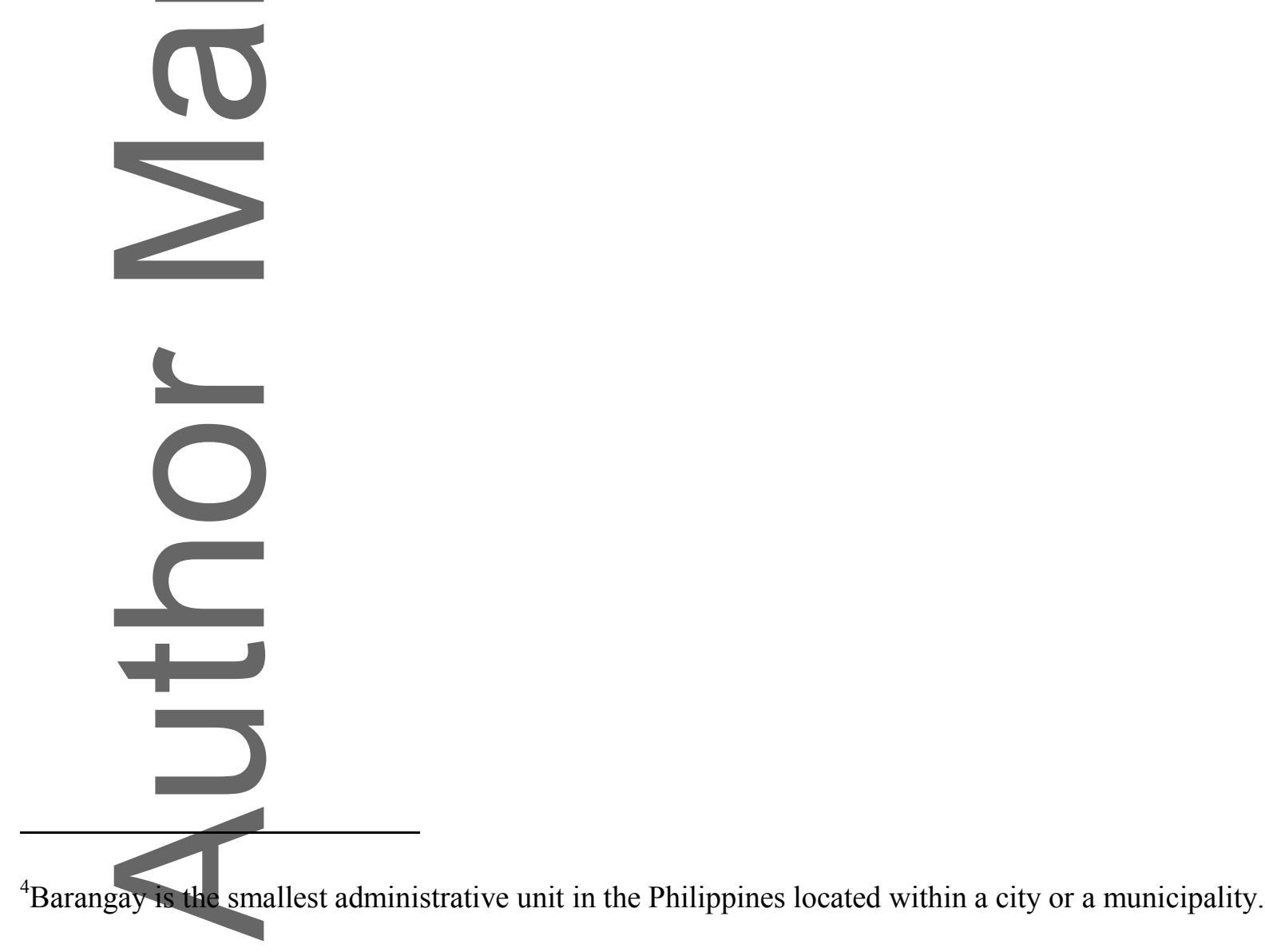

This article is protected by copyright. All rights reserved. 


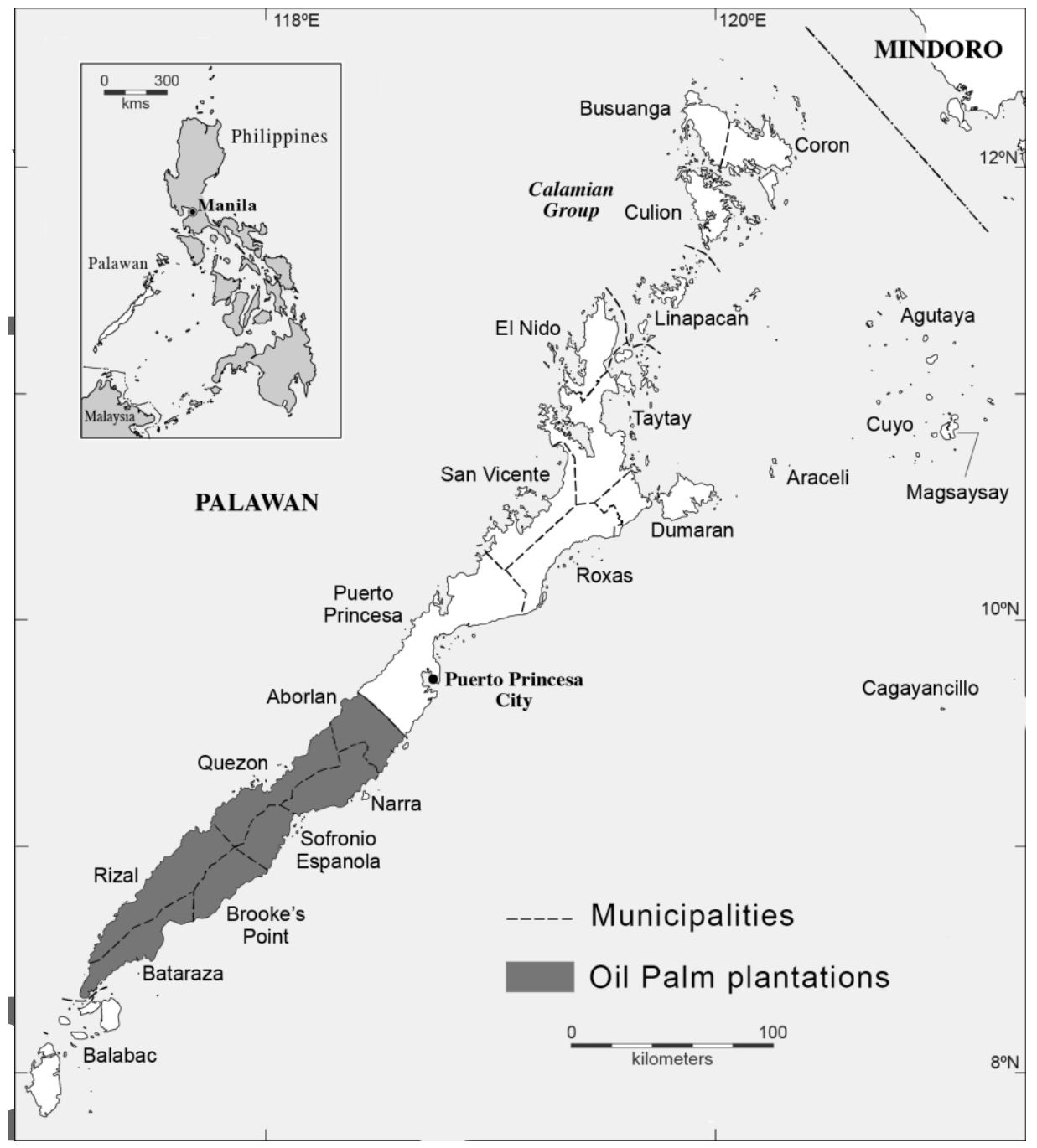

[insert Figure 1 here]

Figure 1: Palawan Island, the Philippines

Note: Mingas and Biluan are located in two barangays in the Municipality of Sofronio

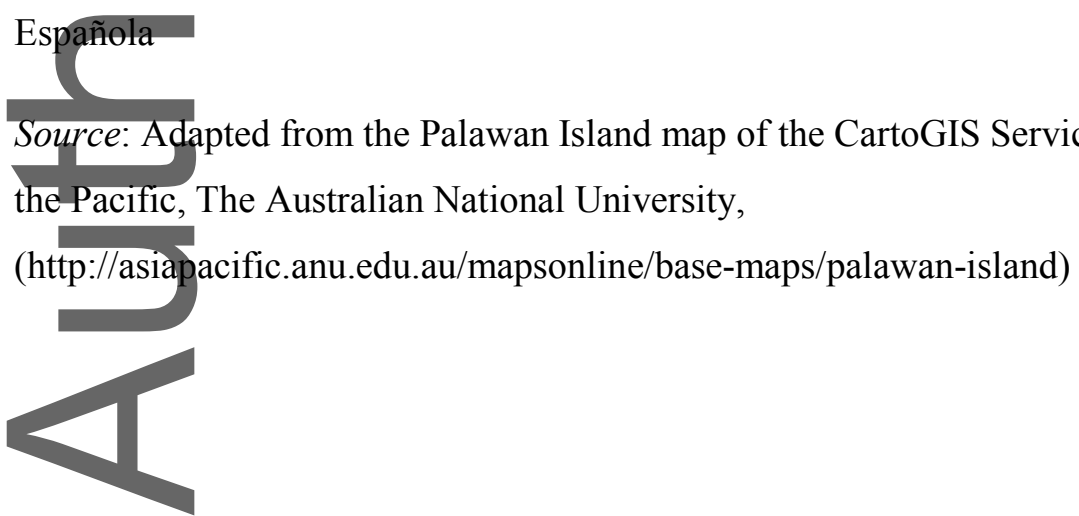

This article is protected by copyright. All rights reserved. 
We carried out semi-structured interviews and participant observation among cooperative members and smallholders to learn about their experiences in managing and/or labouring for the cooperatives; in negotiating their access to and use of food vis-à-vis their livelihoods and the plantation regime; and in dealing with proponents of oil palm plantations and among each other. We interviewed a variety of smallholder farmers (41 Pala'wan and 30 migrants), cooperative officials and plantation managers involved in oil palm production. Interview participants were selected using purposive sampling, with attention to representativeness according to ethnicity, gender, age, location and engagement in the oil palm plantation (e.g. member landowner, non-member, member and labourer). We resided among Pala'wan farmers to learn about their experiences in labouring for the cooperatives and in negotiating their access to and use of land and food by way of their livelihoods and the plantation regime. Relevant documents such as outgrower contracts and food provisioning receipts were collected and examined when allowed. We use pseudonyms for individuals and organizations, including the two cooperatives.

\section{SITUATING FOOD SECURITY}

\section{Food Security and Livelihoods}

Food security studies have undergone several conceptual shifts in the last four decades. The first shift was from an emphasis on the supply side of food to identifying causal links between the experience of food insecurity and socio-economic circumstances (Maxwell, 1996; Maxwell and Smith, 1992). This broader shift in understanding the concept progressed from straightforward assessments of poverty and incomes (Reuttinger, 1977) to prioritizing basic needs (Stewart, 1985) to foregrounding entitlements and human capabilities (Drèze and Sen, 1989; Osmani, 1993; Sen, 1981, 1992, 1999). Sen's seminal entittement approach initiated a major rethinking that global and national level poverty and food insecurity arose simply due to a lack of food supply and availability (Devereux, 2001; Pinstrup-Andersen, 2009). Sen's much-lauded work drew attention to the neglected issue of access and distribution of food so often obscured by the dominance of availability discourse. In particular, he

This article is protected by copyright. All rights reserved. 
elucidated how broader political economic factors mediated and constrained the ability of individuals to access and use their legitimate rights and opportunities to secure food through various politico-legal pathways (Sen, 1984). In time, definitions of food security have become more comprehensive to involve 'access by all people to enough food to live a healthy and productive life' (Pinstrup-Andersen, 2009: 5).

The second shift involved attempts to bridge broader political economic analysis with local livelihood processes and food security. Further research emphasized the multi-dimensional, locally situated nature of food sourcing at the household level, critically engaging the etic orientation of earlier food studies (see Maxwell, 1996). The study and definitions of food security soon encompassed many of its so far neglected socio-cultural and biophysical elements, with an integrated focus on the nutritional quality of and preferences in food (Ingram, 2011). Latin American scholars, for example, examined changes to livelihood and food provisioning in terms of the persistence of peasant farming, and the associated risks, uncertainty and security in food production (see Bartlett, 1980). African scholars — those with an applied anthropology, rural development or agronomy perspective began speaking of livelihoods and food production in terms of exogenous-endogenous interfaces, with an emphasis on emic understandings of food stocks and flows and the security, risk and vulnerability of households and communities (Chambers, 1995; Ellis, 2000; Scoones, 1998). Others of a more political economic persuasion further recognized the importance of how social institutions mediate the dynamics of livelihoods and access to and use of food (see Berry, 1989, 1993).

While both the livelihoods and capabilities approach emphasized household and individual-agency with respect to livelihood and food, scholars have continued to critique the still dominant and somewhat narrow, economistic interpretations of livelihoods (Carr, 2013; Scoones, 2009; Wilshusen, 2014). Informed by this critique, cultural economy approaches described a third shift in the framing of food security concerning the socially embedded, recursive nature of institutions that inform access to and use of food pathways (Cleaver, 2002). Granovetter (1985) and Gudeman (1986) developed a substantivist cultural economy approach by engaging the socially embedded nature of economy, such that food production and food security were examined relationally through familial practice (e.g. kinship, ritual, etc) and place (e.g. ancestral lands) in context. The socio-cultural signification and valuing of food (taste, texture, meaning, etc.) soon mattered more, where analysis went beyond

This article is protected by copyright. All rights reserved. 
'commodity price' to capture varied 'spheres of exchange' that include how socio-cultural meanings articulate with monetary value and the materiality of food (see Foster, 2005; Kopytoff, 1986).By this time, then, the definitions of food security (at least internationally) were more multi-faceted — it 'exist[ed] when all people, at all times, have physical and economic access to sufficient safe and nutritious food to meet their dietary needs and food preferences for a healthy and active life' (Pinstrup-Andersen, 2009: 5).

While these approaches all have their own merits, none sufficiently capture how changing livelihoods, food production and food security articulate with local agrarian change in the global South. New calls have emerged (see Dressler et al., 2017; de Haan and Zoomers, 2005) for livelihood and food studies to capture the socially embedded, contingent and coconstituted nature of food security in the context of uneven agrarian political economy, with greater attention to political power, authority and legitimacy.

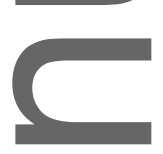

\section{Critical Agrarian Studies and Social Relations}

Contemporary agrarian studies have endeavoured to elucidate the rural poor's struggles over access to-and use of land and forests, as processes of capital accumulation unfold in the context of frontier extractivism, biofuel production and infrastructure development (Bernstein, 2010; Borras et al., 2011; Hall, 2011). Various critical studies have analysed the political economic processes of deepening capital flows and expansion, resource enclosures and commodity production that inevitably confront issues of food security (Borras and Franco, 2012, 2013), particularly when smallholders are involved in intensifying commodity relations associated with new enclosures. Other studies have examined how rural households negotiate food security in relation to the convergence of local political economic, social and biophysical factors, such as the introduction of biofuel production, migration and climatic change (Bonnin and Turner, 2012; Li, 2014; Perrault, 2005).

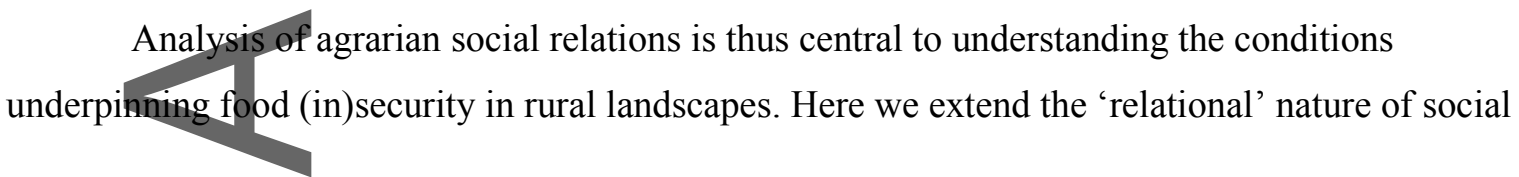

This article is protected by copyright. All rights reserved. 
relations of production and exchange and differentiation to family farm labour being incorporated as 'cheap labour' into expanding plantation regimes. As familial social relations become incorporated into commodity relations on grossly uneven terms, they can either assuage or exacerbate the food insecurity of rural households and or social groups, depending upon their control (or lack thereof) over land, labour and capital (Bernstein, 2010). Such social relations are infused with social identities that are expressed in ways that reflect the degree to which differentiation unfolds in a relational manner at the local level (e.g. 'us versus them', see Dressler and Turner, 2008). The intensity of differentiation informs the degree to which marginalization might constrain access to and use of forest and lands that underpin diverse upland food pathways (Bernstein, 1979).

Uneven social relations of production and exchange emerge, sharpen and are entrenched through the intensifying commoditization of land and labour that in time constrains familial food production. While seldom absolute, commodity relations will intensify as upland households increasingly reallocate their domestic labour towards supporting the production of a greater number of commodities for markets. In the process of being drawn from their lands - coercively, compelled or 'freely' - upland farmers become more fully incorporated as wage labourers to produce for external markets forincome in order to meet domestic needs. In time, deepening patron-client relations and debt bondage can force households to allocate more labour time, income, and savings to repay debt, and thus secure food from the very markets they labour for and others control (see Gerber, 2013, 2014).

As goods become more expensive (e.g. from rice to oil palm) and debt increases, household reproduction may involve the purchase and consumption of the commodities (they labour for) to meet domestic needs that were once largely satisfied by mixed (subsistence-commercial) production and associated social relations. In time, household reproduction becomes increasingly alienated from customary practices, as sovereign control over land and food declines as individualized commodity relations intensify (Jansen, 2015). Long-standing social relations such as reciprocal labour exchanges become less relevant or are renegotiated, as household and individual cash 'transactions' bypass nonmonetized social relations. As households are further incorporated into commodity relations associated with cash crops (e.g. wage labour for oil palm) they often lose their ability to produce, access and use their own domestic surplus (such as swidden rice).

Overall, this process can induce food insecurity. Indigenous households are further marginalized as they are drawn into the local economy's periphery due to an inability to access their

This article is protected by copyright. All rights reserved. 
own surplus for food and/or profit. Meagre incomes are sapped by perpetual cycles of debt and servitude to those mediating contractual arrangements and owning productive capital (Bernstein, 1979). As uneven social relations of production and exchange manifest community-wide, socioeconomic differentiation can emerge more broadly. That is, when social groups who once shared common characteristics begin to differ from one another with respect to those characteristics changing, due to wealth and prejudice, among others. In such contexts, studies have shown how wealthier smallholders act upon and structure the actions of others to impact upon the way food is distributed or made available (Carr, 2006; Li, 2014, 2015). Cooperatives actively mediate similar processes in southern Palawan.

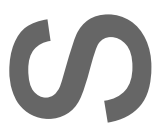

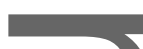

\section{Relationality and Securing Food}

A more nuanced interpretation of agrarian social relations suggests that differentiation and class formation are processual, recursive and infused with agency in even the direst of conditions. Indeed, smallholder families work social relations and kinship ties to negotiate the constraints of differentiation in strategic ways so as to ensure access to and use of food pathways, with customary practices converging with commodity relations and flows (Appadurai, 1996; Foster, 2005; Kopytoff, 1986). Social relations enable processes of negotiation to 'move, acquire, and exchange ideas and resources' (Berry, 1997: 1228). They may support familial well-being when the going gets tough by creating, maintaining or enhancing access to diverse subsistence and or commercial foodstuffs (ibid., 1989), or even the productive capital owned by local elites (Dressler and Fabinyi, 2011).

Differences in farmers' responses will depend upon past and present circumstances, and how these define their positions relative to those of others. Indigenous identities, for example, may be articulated as positions of strength, or as a source of shame due to sustained prejudice (Dressler and Turner, 2008). In general, then, while smallholder social relations are clearly subject to structural constraints, they are often reworked in creative ways to secure claims over food production pathways with some certainty over time. In this sense, social relations that articulate with production and exchange are not wholly subservient to custom or capital, or beholden to specific institutions. Given that sociatrelations are recursively constituted — through, for example, changing lifeways and

This article is protected by copyright. All rights reserved. 
struggles over access - farming families under capital duress may still negotiate productive openings by reworking social networks and economic channels in order to secure food pathways (Sikor and Lund, 2009)

Our article emphasizes the need for food security studies to draw on agrarian political
economy, white being attentive to the situated, relational and emic notions of livelihood change and trajectories of food security. We therefore offer an integrative, comprehensive definition of food security: when all people, at all times, have sustained socio-economic, cultural and physical access to, use of, and control over food that they themselves deem to be sufficiently safe, nutritious, culturally appropriate and that meets their dietary needs and food preferences relative to their changing socioecological context over time and space (Agarwal, 2014; Pinstrup-Andersen, 2009: 5).

Agrarian conceptualizations of food security offer both nuance and complexity in understanding how institutional arrangements (e.g. cooperative production regimes) influence food security pathways - those social, economic, cultural and material openings available for access and use of the right type and amount of food by smallholders. As we discuss, cooperatives are in themselves institutional artefacts of agrarian social relations that impact upon smallholder food security pathways in frontier lands; they come to mediate labour relations, income, debt, food distribution and ethnic relations through plantation regimes that are subject to the broader politics and power of state and non-state institutions. A relational approach allows us to examine further how cooperatives mediate social relations that possibly constrain smallholders' food security, while also being attentive to the various ways farmers negotiate these changing social relations.

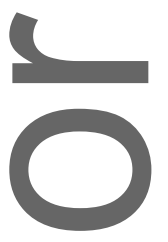

\section{PALAWAN AND LIVELIHOODS IN CONTEXT}

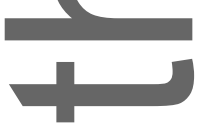

Palawan is one of the fastest developing provinces in the Philippines, with rapidly expanding plantation regimes and resource extraction in the south (Eder and Evangelista, 2014). The province is home to a significant population of indigenous peoples (mainly Tagbanua, Batak and Pala'wan) and a growing number of migrants who settled in Palawan from other provinces to secure land holdings and other economic opportunities. The national and provincial governments and private investors have

This article is protected by copyright. All rights reserved. 
promoted Palawan as a promising area for agro-industrial development, particularly oil palm production (Montefrio et al., 2015). Since the mid-2000s, oil palm production areas have grown to cover more than 4,500 ha in seven municipalities in the southern part of the island.

The oil palm-growing municipality of Sofronio Española is home to Christian Visayan and Muslim migrants originating from the Philippine islands of Visayas and Mindanao, respectively, and the indigeneus population of the Pala'wan. In the communities where the two cooperatives we examined operate, Pala'wan households still constitute about a third of the total population. Most nonindigenous smallholders reside in the lowlands and along the coast and rely on wet rice cultivation, coconuts and livestock production, fishing, retail businesses, and off-farm wage labour. These farmers tend to be migrants (tenured or recently settled) who by virtue of their own livelihood histories, sociopolitical relations, ethnicity and religion often have access to formal tenure mechanisms, in particular private title and the Certificates of Land Ownership Awards (CLOA) granted through the Philippine government's Comprehensive Agrarian Reform Program (CARP). In many cases, these farmers were the first to reorganize or establish cooperatives now connected with oil palm production.

Pala'wan farmers reside in forested upland areas where they rely on uma (swidden), swidden fallows, home gardens, non-timber forest products (NTFPs), and intermittent wage labour activities on the fields of migrant smallholders, and now oil palm plantations. Engaged in complex livelihoods, many Pala'wan families may have several swidden fields (in cultivation and fallow) from a quarter (padaka) to one heetare in size, and grow multiple varieties of rice, fast-growing root crops and other cereal crops. Such fields are left fallow between two and seven years, depending on whether farmers have access to sufficient unclaimed lands or are using the land of other farmers. Pala'wan farmers tend not to have formal tenurial security, apart from collective Certificates of Ancestral Domain Title (CADT) awarded through the Indigenous Peoples Rights Act (Republic Act 8371). ${ }^{5}$ However, many Pala'wan groups have had difficulty securing CADTs, including those in this study, due primarily to the weak implementation of the policy (Montefrio, 2014). Hence, many rely on less formal tenure arrangements such as local government recognition of tax declarations and the temporary (25-year) renewable forest management leases awarded by the Department of Environment and Natural Resources (DENR). As the vast majority of Pala'wan hold land in usufruct, particularly swiddens, they have limited legal recourse in controlling whether their lands are used for oil palm plantations or

${ }^{5}$ For more information, see http://extwprlegs1.fao.org/docs/pdf/phi13930.pdf

This article is protected by copyright. All rights reserved. 
not; by default, they thus have little influence over the establishment and objectives of cooperative structures and local labour conditions.

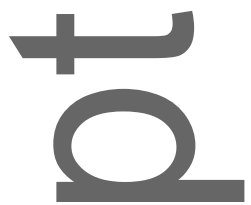

(

PALA'WANFOOD PRACTICES - IN BRIEF

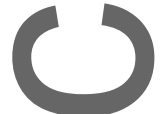

Pala'wan farmers have maintained degrees of food and livelihood security for centuries in the uplands of southern Palawan (MacDonald, 2007), despite being subject to major livelihood shocks and stresses such as El Niño, sickness and debt. Swidden rice cultivated in the uplands remains central to Pala'wan subsistence and sense of food security. Known intimately by flavour, texture, aroma and yield, swidden rice figures prominently into ritual, ceremony and other familial practice, and makes it the most desired staple. As with other indigenous groups, Pala'wan understanding of swidden rice production informs their broader sense of being 'food secure' from an interrelated socio-cultural, biophysical and caloric perspective. For example, glutinous varieties of rice (meragket) figure into post-harvest thanksgiving offerings called lutlut (glutinous rice cooked with water or coconut milk and other meats inside a bamboo shaft) and, in mixed Pala'wan-migrant households, the making of suman (rice cake) treats for children. Non-glutinous varieties (marungras), such as Tipak, reflect volume upon cooking and a feeling of being full and content for those consuming such varieties (Smith, 2015). The primacy of rice in the upland diet is further reflected in constant efforts to trade root crops, other non-timber forest products (NTFPs) and, as we show, one's own labour on plantations, for sacks of rice (Fabinyi et al., 2017).

During 'months of hunger' (that is, when rice stocks are low at the end of the dry season in May to June, before the main harvest in September), Pala'wan families rely on the starchy root crops they produce in swidden fields. Such root crops — including the high yielding sanglakayu (cassava, Manihot escutenta), sanglay (sweet potato, Ipomoea batatas), tales (taro, Colocasia esculenta) and ubi (purple yam, Dioscorea alata L) - serve as important staple foods (after rice) for households; emphasizing the importance of starchy staples in indigenous diets more broadly (see Novellino, 2007; Warner, 1979). If domesticated varieties become scarce such as in the drought conditions of the last

This article is protected by copyright. All rights reserved. 
two El Niño events, emergency root crops such as kedut/korot (Dioscorea hispida Dennst) and wild yams may also be sourced from the forest fringes of swiddens (Smith, 2015).

After rice and root crops are harvested, corn is also often grown for consumption, sale or feed for livestock. A range of other crops - such as punti (banana, Musa spp.), mangga (mango, Mangifear indica), kalamansi (calamansi, Citrofortunella microcarpa) and nengkaq (Jackfruit, Artocarpus heterophyllus) - are usually only planted in fields after rice, root crops, and maize have been harvested, or near the edges of fields so as not to overshadow the rice. In time, tree crops tend to comprise important food sources in maturing swidden fallows further from the main homestead. In contrast, vegetables (eggplants, string beans, bitter gourd, etc.) and legumes (green beans) are grown in gardens closer to the house to supplement daily meals, particularly when meat (as viand/ulam) is unavailable

NTFPs also figure prominently in Pala'wan notions of food security. Traditionally, Pala'wan smallholders have harvested and hunted a wide variety of NTFPs including wild animals such as biek talun (wild boar, Sus barbatus palawensis), deges (honey), and eniraq (bee larvae) from hives as important sources of vitamins, minerals and protein. In difficult times, the cash from the sale of NTFPs, for example, tapping of begtik (Almaciga, Agathis philipinensis) and harvesting of uwey (Calamus spp), rebuk (bamboo), and coconut palm fronds, is also used to purchase rice from the lowlands.

Given the Pala'wan's reliance on forests and swidden, a typical household meal will vary seasonally and is strongly influenced by climatic events (Smith, 2015). While cooked rice and starchy root crops have always been central in everyday meals, particularly in difficult times, no meal is necessarily complete with just cooked rice alone. Typically, a full, complete and nutritiously satisfying meal includes a complement of both rice and isdaqan (fish, protein viand), typically vegetables (in difficult times) and/or sedaq (marine or smaller riverine fish). In bountiful times, wild game (wild boar, Palawan Peacock, bat, etc.) also serves as viand (Fabinyi et al., 2017).

Pala'wan food consumption also includes a range of modern goods, with the frequency of consumption varying across families, income and residential location. In the remote uplands, one typically finds fewer households who consume food products such as canned sardines and noodles, whereas in the mid-elevations and downslope, the tendency for households to consume such products increases (due to more cash income and credit). Other products such as dehydrated coffee and

This article is protected by copyright. All rights reserved. 
processed sugar are highly desired and consumed whenever possible. Most poor, forest-reliant families in the uplands consume such products infrequently (see MacDonald, 2007).

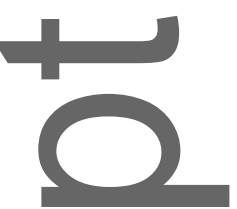

1

\section{FOOD (IN)SECURITY AND OIL PALM DEVELOPMENT}

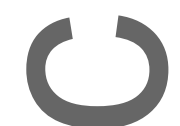

The prospect of food security in the oil palm-producing communities of upland Palawan is interlaced with complex local agrarian political economies, institutional (re)arrangements and environmental change. While Pala'wan farmers have frequently faced difficulty in ensuring food security due to El Niño-induced droughts (Smith, 2015), declining rice yields due to shorter fallows (poorer soil conditions), less land due to migrant land claims and the introduction of oil palm in 2006 has further accelerated the process. Indeed, more and more smallholders are participating in plantation wage labour as they witness more intense incidences of land use conversion and land control (Dressler, 2017; Montefrio, 2017). We now examine how the emergence of oil palm plantations and cooperatives articulate with the agrarian political economy associated with land control and wage labour. We then detail the associated social relations of debt and prejudice that have become accentuated as Pala wan farmers become further incorporated into intensifying commodity relations broughtabout by the cooperatives and plantation regime.
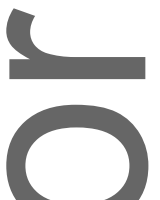

\section{Cooperatives in the Palawan Oil Palm Regime}

Oil palm development in Palawan began in 2003 when the provincial and local governments invited a partially foreign-owned private company (hereafter SunSol) to explore producing oil palm in the province. In 2006, SunSol officially began its operations and has since established more than 4,500 ha of oil palm plantations in southern Palawan. Production is divided into two schemes: anchor sites and outgrower production. In the anchor scheme, landowners lease their land to SunSol for 15 years, with annual rent per hectare varying on plantation yield annually (year $1=\mathrm{PhP} 1000 /$ ha; year $3=\mathrm{PhP}$

This article is protected by copyright. All rights reserved. 
3000/ha, etc.).

In the outgrower scheme, agricultural cooperatives are formed or reformed from older ones to engage in tripartite contracts with SunSol and the state-owned, Land Bank of the Philippines (LBP). The LBP provides loans to the cooperatives (for developing the plantations in the outgrower scheme) based on stringent requirements. SunSol acts as guarantor to support the loan application of the cooperatives and uses registered farmer land holdings (including usufruct swidden lands registered de facto) as collateral for the loan and its future repayment. In the case where partner cooperatives are unable to produce the required equity (usually 20 per cent) for the loan, SunSol offers to loan them funds as well, with compounded interest rates ( $\sim 14$ per cent) comparable to those imposed by the LBP. A typical outgrower contract mandates the oil palm company to (1) manage the finances (including the cooperatives' loans) and everyday operations of the plantations, (2) provide training, inputs and market guarantee, and (3) share production profits with the cooperatives. SunSol can also collect a fee of 10 per cent of the profits for the plantation management services it provides the cooperatives

Since 2006, many agricultural cooperatives had been enrolled in the outgrower scheme. With the assistance of national and local government offices related to agriculture and agrarian reform, SunSol had targeted pre-existing cooperatives to enrol in the outgrower production regime and recruit landowners for its anchor production areas. After a series of meetings and seminars in 2005-06 between the cooperatives, oil palm representatives, and other migrant farmers about the apparent benefits of oil palm, the cooperatives' Board of Directors immediately began the local enrolment process.

The two cooperatives we examined - Mingas and Biluan — were enrolled in the first few years of oil palm development in the province. Prior to becoming involved in oil palm, the two cooperatives were established to provide capital assistance for migrant farmers (tenured and new arrivals) engaged in the production of other cash crops (e.g. rice and coconut for Mingas; coconut and jatropha for Biluan), which meant they were already serving wealthier 'land-endowed' farmers. With the lure of windfall profits, the pre-existing leadership of the cooperatives then reorganized for oil palm and simultaneously enticed existing members (mostly migrant farmers) to participate and offer up their existing (paddy and orchard) lands for production. The cooperative board of directors was entitled to control who it could recruit as members, the land to be included in the outgrower scheme, the organization of labour in the plantation (e.g. who works, when they work, and what and when they

This article is protected by copyright. All rights reserved. 
get paid for work), and the disbursement of profits to its members. ${ }^{6}$

With increased enthusiasm for the project, cooperative boards and officials - still dominated and controlled by wealthier Christian Visayan and Muslim migrant landowners — proactively recruited indigenous and migrant landowners (often with promises of major benefits) to join the outgrower scheme, thereby significantly increasing membership in both cooperatives. Mingas started with only 25 members at the outset, for example, and expanded its membership to more than 100 . While those who had filled official positions in the cooperatives already held large tracts of titled land planted to oilpalm, other lesser-privileged migrant and mixed Pala'wan-migrant households (some of whom had secured CLOA titles) had only enrolled later in the outgrower scheme. As a LBP requirement for loan applications, membership was initially limited to those who have formal land tenure such as a CLOA. After other loans were obtained, however, more Pala'wan farmers were enlisted, leading to the inclusion of significant tracts of land with less formal tenure arrangements (e.g. tax declarations) or usufruct lands with none at all. Overall, membership thus remained uneven, with the few Pala'wan in the cooperatives holding little, if any, power - effectively relinquishing their rights to land.

The tendency of both cooperatives to exploit 'cheap' untitled indigenous land and labour was also partly reflected in their mounting debt. Underestimating the maintenance costs of plantations, the cooperatives requested additional loans from SunSol, initially with a compounded interest rate of 14 per cent and then eventually negotiated down to 7 per cent. With the difficulty of realizing production targets, the cooperatives failed to meet the loan amortization schedule, disburse profit shares to members and pay the wages of labourers. In the context of needing to overcome establishment costs, cheaper land and labour continued to be drawn from nearby Pala'wan communities, where the gruelling conditions and low wages did not equal the hard work of weeding, spraying and harvesting.

Initial meetings between the cooperatives and SunSol suggested that the company was willing to allocate more space (about half) in their production for the outgrower scheme. This would allow participating farmers to benefit more from the sharing of profits from harvest, which was significantly higher than rent from the anchor sites. Farmers who volunteered lands as part of the outgrower scheme recalled premises of Php 5,000 per hectare per harvest (i.e. every 15 days). However, with no written documentation from the initial meetings between the cooperatives and SunSol, landowners

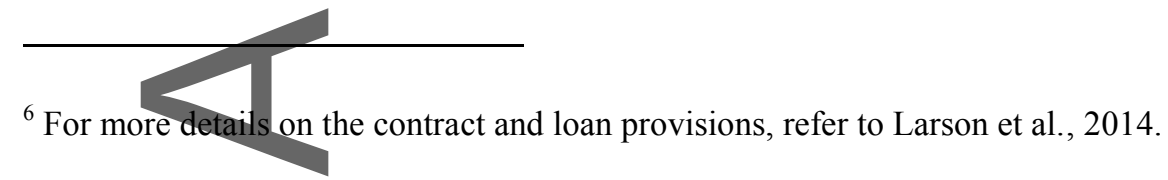

This article is protected by copyright. All rights reserved. 
had little if any redress for the eventual non-existent profit shares and heavy debt incurred in the last few years. Many Pala'wan plantation labourers were similarly affected by this arrangement.

In time, StnSol's anchor sites continued to expand at the perceived expense of the cooperative outgrower production sites. The anchor site expansion began immediately after plantation agreements were signed and the cooperatives applied for start-up loans from LBP. In the time it took for the loans to be issued to the cooperatives, SunSol had expanded the anchor lands significantly. In one barangay, for example, oil palm plantations grew to 1,000 hectares in less than 10 years, with anchor sites eonstituting 75 per cent of the total production area. With this shift in production, SunSol was setting out to secure more profit through the anchor area and so bypassing the promised development of the outgrower area through the cooperatives. The outgrower cooperatives appeared to have less autonony to negotiate and manoeuvre in the oil palm regime. While the outgrower scheme ought to be a 'partnership' between SunSol and the cooperatives, the former had more control over daily operations (including the management of the cooperatives' loans), while the latter absorbed the majority of financial and managerial risks and had limited control over the plantation's management (Larsen et al., 2014). ${ }^{\text {? }}$

The confluences of expanding oil palm plantations, the concentration of land among the migrant cooperative leadership and membership base, the growing debt of cooperatives, the rise of incorporating indigenous lands, and poor labour conditions have had critical implications for Pala'wan farmers' food security. Under the aegis of the cooperatives, Pala'wan farmers have found their fallow and swidden lands progressively incorporated and or flanked by both anchor and outgrower plantations. In the process, they have seen an increase in the use of food stuff (loaned on credit) and a gradual reduction in access to and use of subsistence production and food.

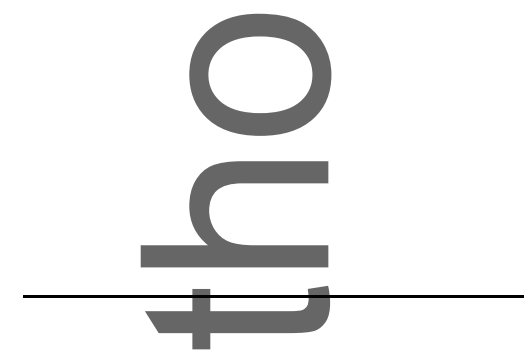

7 In 2014, for instance, we noted numerous instances when Biluan had to consult SunSol on matters pertaining to labour issues and delays in wage payments. There were also allegations of SunSol usurping the authority of the cooperatives, by, for example, completely excluding cooperatives from financial management, enrolling farmers in the outgrower scheme without the cooperative officials' knowledge, involuntarily enrolling farmers in the outgrower scheme, among others (see Larsen et al., 2014 for more discussion). Cooperative members then have become increasingly disappointed and suspicious of SunSol's role in the outgrower scheme.

This article is protected by copyright. All rights reserved. 


\section{Land Control and Declining Yields}

In less than a decade, oil palm expansion in the municipality has created local political, economic and biophysical conditions that have made it increasingly difficult to access sufficient fallow lands for swidden and to sustain adequate yields of upland rice. The entry of plantations has exacerbated longstanding problems that began when migrants entered lands long used by the Pala'wan. In the months leading up to the plantation's establishment, a land rush ensued with migrants claiming or purchasing tens of hectares of land in order to secure greater rent from oil palm development. Migrant landowners originally saw the entry of the oil palm company as providing opportunities to earn from lands that they claimed but viewed as 'unproductive' and 'idle'. With the arrival of oil palm in 2006, land prices have escalated and resulted in speculative land buying. Offers to buy fallow land had risen drastically from $\mathrm{PhP} 3,000$ ( $\sim \mathrm{US \$}$ 60) to $\mathrm{PhP} 15,000$ ( $\sim \mathrm{US} \$ 300$ ) per hectare in a short period of time. ${ }^{8}$ The prospects of investing in land was perceived as profitable for those who had resources to buy it, especially when a productive hectare of oil palm could fetch as much as PhP 70,000 ( US\$ 1,400 ) annually (rates as of 2012). As a result, both SanSol and cooperative leaders were actively brokering land sales as a means to capture these ancestral lands as prospective sites for oil palm production. Indeed, many cooperative leaders had used their political clout, authority and legitimacy to facilitate land brokering and enrolment of farmers into contract farming. Moreover, after the initial sections of the plantations were established, without consultation, migrants had claimed more 'idle lands' from ancestral territories to be zoned for oil palm development.

Taken together, migrant land claims, an aggressive land market and state restrictions on swidden expansion have increasingly limited Pala'wan farmers' ability to access and use their own land for domestic food production. In this context, many farmers have increasing difficulties in borrowing and using lands from other family members or farmers. Although copra, paddy rice and mining had also constrained the availability of fallow lands that could be borrowed, the arrival of oil palm has made such land sharing increasingly necessary but ever more difficult to achieve. Indeed, many of those lands previously borrowed were either already committed to oil palm production or sold to prospective oil palm growers. In other cases, landowners who had not yet committed to oil palm now demanded rent in the form of sharecropping (e.g. one to two sacks of rice for every hectare of land rented) (Montefrio 2017). Given that swidden yields were already low, the added

${ }^{8}$ Based on 25 November 2016 exchange rate.

This article is protected by copyright. All rights reserved. 
sharecropping arrangements has placed an additional burden on Pala'wan farmers' ability to produce rice and secure NTFPs. As the Pala'wan farmer, Liban Anto, lamented: 'It is still a burden to pay one sack ... especially when the yields are low. Sometimes we only get 10 sacks per harvest, and when you have a family that is not enough ... but we rent just so we can continue uma (swidden) ${ }^{9} .{ }^{9}$ With less land available, Pala'wan smallholders have intensified swidden production by, for example, depending on greater inputs (e.g. fertilizers and herbicides), extending cultivation of land, or leaving swidden fields in a reduced one to two year fallow. With limited revenue from swidden sales, other Pala'wan farmers' only financial recourse was to sell their remaining lands to migrants and absentee landowners, who then committed these lands to oil palm production.

Several Pala'wan farmers also claimed that the recent decline in upland rice yields was partly attributed to the proliferation of oil palm. Radya Buntar, a female Pala'wan smallholder, lamented, '[n] ow [upland rice] harvests are dismal. Before I could still harvest 40 or 50 sacks, but just this year I only managed to get $10 \ldots .{ }^{10}$ Other Pala'wan farmers also attributed the dismal yields to pest infestations from nearby oil palm plantation. Smallholder Felima Bucal explained 'before the oil palm, we could get 10 cavan (sacks) from a quarter hectare of swidden. That was when there were no pests like black bug. But now, if we have money and we buy chemical sprays, we can only get 10 . But if we don't, there is no palay (rice) ... our palay is infested by black bug and tyangaw (rice bugs)'. A number of farmers believe this to be true. According to Manny Mascada, "what I know is when the palm oil came, rats also started infesting our palay. Before there were no worms, black bugs, or insects' 11 The combined effects of reduced access to swidden fallow lands due to local dynamics of land control and declining rice yields brought about by pest infestation have contributed to food insecurity among Pala'wan swidden cultivators. Such circumstances have compelled Pala'wan farmers to depend on other sources of income and the oil palm plantations have provided labour opportunity for a few.

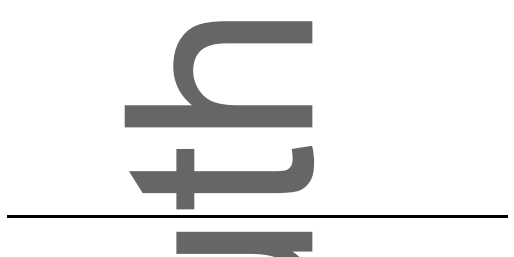

\footnotetext{
9 Interview, Liban Anto, Pala'wan smallholder, April 2012.

${ }^{10}$ Interview, Radya Buntar, Pala'wan smallholder, March 2012.

${ }^{11}$ Interviews, Felima Bucal and Manny Mascada, Pala'wan smallholders, May 2015.
}

This article is protected by copyright. All rights reserved. 


\section{Oil Palm Labour and Income}

The expansion of oil palm has provided various wage labour opportunities for both Pala'wan and migrant smallholders since 2007, including clearing of land, planting of seedlings, maintenance of plantations (weeding and applying fertilizers and herbicides) and harvesting. The initial workforce was signifieant, ampunting to a few hundred, with mostly Pala'wan smallholders as the initial labourers who cleared (their own ancestral) forests for the plantation. Primarily elicited by chronic problems associated with swidden production overall, Pala'wan smallholders were often enthusiastic to work in the plantations at the outset. Most signed up to help augment their family earnings to secure food suppties and continue sending their children to public school. One female Pala'wan oil palm labourer, Melinda Obrid, noted that while copra production brought in cash, 'it was not enough for the family, that's why we applied for work at the oil palm. We thought we could send our children to school'. ${ }^{12}$ It was in this context that cooperative officials and plantation supervisors became central in recruiting labourers, often communicating the availability of work on a biweekly basis. As one Pala'wan worker, Alexis Manga, noted, 'We heard that the manager was looking for labourers at the palm oil and we asked if there were any openings for us. We submitted our application and the following morning we were hired. We were told we would have a daily, steady income for our family. But we only get 215 pesos per day'. ${ }^{13}$

Although-smallholders perceived the plantation wage as helpful in augmenting household incomes, they also saw this income source as insufficient in securing their household's daily food needs and sundries. Daily wages were below the mandated minimum in rural Palawan and labourers were required to pack their own food when they worked in the fields. ${ }^{14}$ More importantly, due to mismanagement of funds and the less than productive yields from the oil palm plantations, payment of wages (paid bi-monthly or every 15 days) had been delayed for as long as two months. Many of

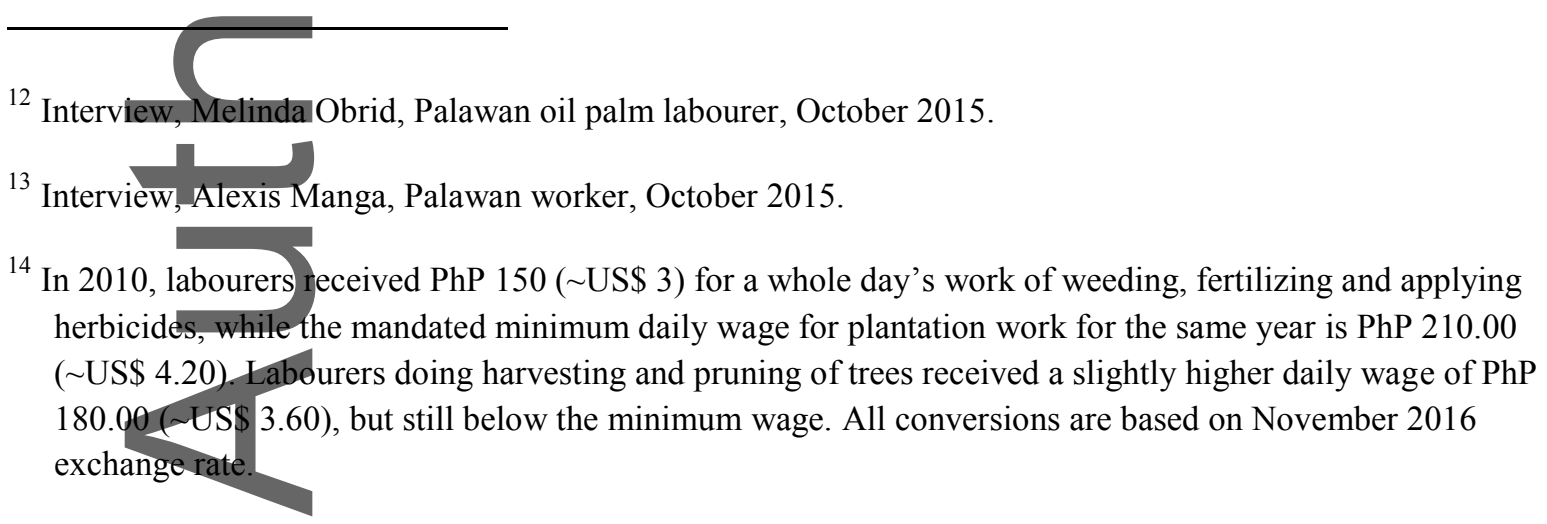

This article is protected by copyright. All rights reserved. 
them, particularly indigenous labourers, emphasized how delays in wages significantly affected their ability to secure rice for their families. Since many work the whole day in the plantations - in some cases having both male and female household heads working for the same cooperative - they often had difficulty sourcing other work for varied incomes and finding the time available to acquire nutrient-rich forest foods. One Pala'wan farmer, Permin Salvator, recounted:

-

(1)

The wage is low. I do not consider it a fair wage and sometimes our wages are delayed by 15 days ... so what will happen to the poor? We can't wait that long; we endure by just eating dried fish every day for us to have food, and even though the wage is low, we still endure as it's better than not having any work at all. But because of the oil palm now, we cannot easily till the soil or burn for our kaingin [swidden] for food. ${ }^{15}$

However, the number of Pala'wan labourers employed by the cooperatives has been declining over time. Pala'wan smallholders were actively recruited in the early days of the plantation development due to their perceived skill in clearing, burning and planting, especially in the upland sites where the majority of the oil palm plantations are situated. This work was considered to be similar to their traditional swidden practices. Over time, as the work required long-term maintenance and harvesting, the labour force shifted towards a migrant majority with fewer Pala'wan interspersed among them. Based on our field research, there were several possible reasons for this shift: the cooperatives eventually preferred hiring migrant labourers; some Pala'wan smallholders limited their involvement in oil palm wage labour, claiming that they could not work the whole day and deal with the protracted, bi-monthly payment schedule (given their immediate cash needs); and many Pala'wan smallholders eventually saw plantation work as conflicting with swidden farming and other household duties. Labourers were expected to work six days a week from 7 am to $4 \mathrm{pm}$, and sometimes longer. Initially, there was no motorized transport provided and plantation labourers left home early ( $5 \mathrm{am}$ or earlier) to walk to the work sites. The long hours of continuous work in all weather conditions and the lack of safety equipment had farmers reporting negative health impacts. The socio-physical

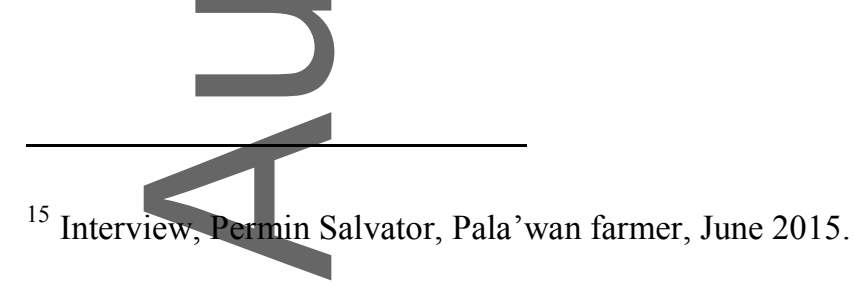

This article is protected by copyright. All rights reserved. 
exhaustion and wear from oil palm labour thus impacted the focus and care the Pala'wan could give to swidden and NTFP harvesting.

Despite declining swidden yields, difficulties in acquiring land for swidden, and pressures to earn income from oil palm plantation work, many Pala'wan farmers continued to view swidden as their primary livelihood activity and food procurement strategy. This meant that many still chose to focus on their swidden plots at key points in the planting cycle while negotiating plantation labour. This resulted in seasonal patterns when Pala'wan workers would 'come and go' from the labour regime. Cooperative officials noted that Pala'wan employment would be higher in the months after harvest (October-January) and before the planting season, and would peak in the months after planting and before harvests (March-August) when rice stores were at their lowest. In times when there was a need to attend to both wage labour and swidden, other family members were asked to tend their swidden fields while heads of households worked in the plantations.

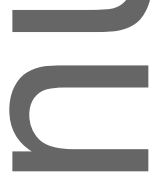

\section{Social Relations of Credit/Debt and Prejudice}

We show next how credit and debt relations and prejudice further reinforced the constraints over food security that emerged from the land control and labour dynamics described above. We treat each theme separately and then aim to integrate how each works relationally to affect Pala'wan food security over time and space. As we argued above, migrant-dominated cooperatives - as embedded in the local political economy of oil palm contract farming - play a significant role in mediating these two forms of social relations.

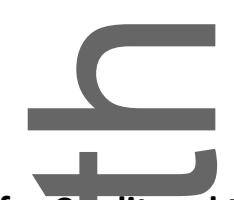

Food for Credit and the Bale System

In rural Palawan, eredit and debt relations often manifest as food for credit through food provisioning institutions such as sari-sari stores. These are small, family-owned variety stores that sell an assortment of food and non-foodstuffs such as rice, canned goods (e.g. sardines), dried fish (e.g. tuyo

This article is protected by copyright. All rights reserved. 
and daing), sugar, salt, coffee, soap, alcohol, chewing tobacco (mascada) and cigarettes) which smallholders purchase on credit. The practice of availing food for credit has taken place ever since sari-sari stores appeared in rural communities and have become an important source of food credit and a partial safety net for indigenous smallholders, particularly in difficult times. However, the purchasing of foodstuffs on credit has intensified among oil palm labourers as payment of wages was increasingly delayed.

In terms of plantation work, the delay in wages had resulted in Pala'wan labourers accumulating bi-monthly debts of up to PhP 2,000-3,000 ( US\$ 40-60) worth of mostly foodstuffs from sari-saristores. This amount is typically much higher than their monthly wages. Due to an increasing number of debtors and the mounting debt, more and more sari-sari stores had denied indigenous labourers credit. Yet some continued to accommodate those farmers who had proof that they were employed as wage labourers in the plantations or elsewhere, this being the basis of keeping labourers fed and working longer hours in the plantations.

More crucially, cooperatives had also resorted to putting up their own variety stores that resemble sari-sari stores, but with the primary objective of serving its members and labourers. The main purpose of cooperatives opening their own convenience store was to diversify income streams and improve their group's financial standing, such as Mingas for example, but a central aim was also to encourage labourers to stay and work on the plantation. In 2011, Biluan was in such a poor financial state that it was delaying payment of wages by four months, consecutively. At the time, plantation workers (both migrant and Pala'wan) who had been denied credit in sari-sari stores and were desperate to make ends meet began organizing labour strikes against the cooperative and the company. In order to placate the labourers, one of the wealthier members of the cooperative's board of directors helped finance the establishment of a cooperative variety store with a bale system to specifically cater to the food needs of the labourers and keep them working on the plantation.

The bale food provisioning scheme thus allowed labourers to avail themselves of limited household goods (primarily food), which were deducted from their (delayed) monthly salary as credit. The value of the goods was capped at a particular percentage of their salary: for example, Biluan capped the loans at 50 per cent of the salary amount, while Mingas at 80 per cent. In most cases, labourers maxed out the cap of what they could loan. The frequency of food provisioning also varied, with Biluan limiting the number of days that labourers could avail (e.g. every Wednesday and

This article is protected by copyright. All rights reserved. 
Saturday), while Mingas did not set a limit. In the case of Biluan, labourers would maximize the number of days in a week that they can have food credit.

Based on actual bale records, the types of food offered in the bale system were of the canned, high-sodium preserved or dried varieties that differed significantly from the traditional, more nutritious mix of food from forest fallows that Pala'wan families would spend timecollecting and harvesting. In Biluan, the foodstuffs offered were limited to a few, such as coffee, processed food (e.g. instant noodles), rice, salt and sugar. In Mingas, the same list was evident, with the most common food procurements being rice, instant noodles, sardines, sugar and coffee. Our Pala'wan respondents also attested that rice, monosodium glutamate (MSG) seasoning, coffee and sugar made up the majority of their food bale, with the occasional purchase of canned goods as requested by their children. The bale records of Mingas revealed a more detailed account, including non-foodstuffs purchased by the planation workers and other farmers. A summary of the highest expenditures from five labourers who drew from the bale system over 212 days showed the following consumption patterns: rice (89 times), cigarettes and alcohol (81 times), milk, coffee and/or hot chocolate (31 times) and sugar (7 times). Pala'wan labourers, in particular, tended to draw more rice from the bale system in periods before swidden harvests during the rainy season, when their household ricestores were typically low or depleted. The imputed financial value of rice loaned for one household amounted to PhP 1,869 ( US\$ 37), which is the salary equivalent of 10-11 days labouring in the plantation.

The frequency of availing of bale and the financial/labour costs incurred suggests that indigenous households have had difficulty in securing a regular food supply over periods of time when they are pulled into the plantation labour regime. The high frequency of borrowing similarly suggests degrees of dependency on the bale system, compelling labourers and their families to consume whatever the cooperatives make available. As Biluan's designated bale caretaker, Marilyn Mendoza, ${ }^{16}$ explained:

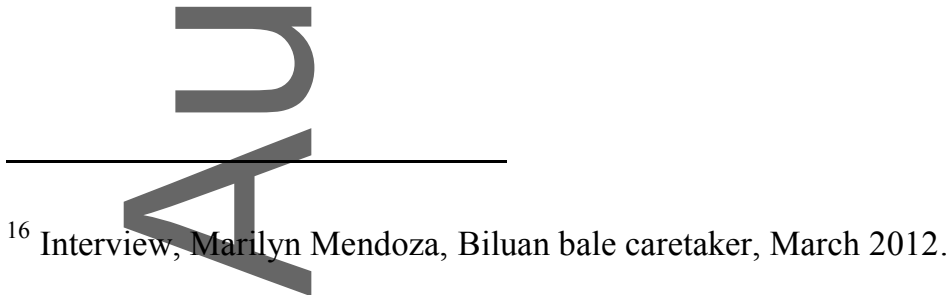

This article is protected by copyright. All rights reserved. 
Almost all of them max out their cap for the bale, and some even go beyond the 50 per cent limit. I take pity on them, so sometimes I allow some to go beyond the cap. What they eat every day is what they get from the bale. They really budget that. For example, one labourer will acquire four gantas (2.1 kilos per ganta of unhusked rice) of rice in one particular bale day, but they will try to portion that for the whole family until the next allowable bale. That amount of rice is sufficient at times, but in most cases, inadequate for the family.

Labourers also complained about how difficult it is to manage their household finances and the debts that they incur from the bale system. Some expressed dissatisfaction with how products offered in the cooperatives' bale were more expensive than those sold in neighbouring sari-sari stores or elsewhere. Although the cooperatives claimed that they charge equal prices to other sari-sari stores of their size, labourers from other plantations in the municipality alleged that this is not necessarily the case for all cooperative stores. Several Pala'wan labourers also expressed concerns about the extra work that they would have to do to repay their debts. In some instances, Pala'wan labourers would have to ringweed more oil palm trees (where payment is based upon each tree completed) in order to repay any foodbased debt ineurred from the bale system. Indigenous labourers who are more and more indebted to the plantation labour regime and rely heavily on bale foodstuffs subsequently have increasingly less time to access and use swidden fallows for traditional foods. In turn, they have continued to rely on expensive foodstuffs of poor nutritional value that undermine traditional social relations (customs, rituals, etc.) and upland livelihoods, across generations.
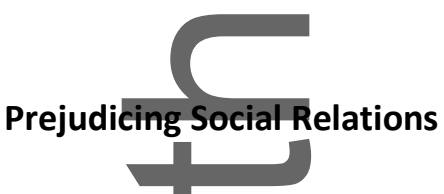

Prejudice against Pala'wan smallholders who work in plantations also reinforced poor treatment, poor pay and indebtedness - interrelated factors that mediate and influence food insecurity. In particular, Pala'wan labourers experienced sustained prejudice from cooperative leaders and migrant plantation supervisors. As many Pala'wan labourers continue to tend their swidden fields, they often do not

This article is protected by copyright. All rights reserved. 
consistently work in the plantations and so split loyalties between each activity. As a result, ethnic tensions between Pala'wan and the cooperative managers and other migrant labourers had risen with derogatory statements targeting indigenous labourers and identity. Cooperative leaders, for example, remarked that Pala'wan labourers tended to work at a slower pace (mabagal), to be hard-headed (matigas ang ulo), to be antisocial (walang pakisama), to be frequently absent, and to often quit work without notice. Joselito, the chairman of Mingas, referred to this work ethic pejoratively as 'weatherweather', meaning that the Pala'wan would only look for work when they thought they really needed it, on an intermittent family-needs and or seasonal basis. ${ }^{17}$ Migrant labourers had also expressed the same remarks when they compared themselves to their Pala'wan counterparts. Pala'wan labourers recognized this prejudice. One Pala'wan labourer remarked:

Sometimes [the leadman] would get angry at us ... if we are really tired and we rest, they would say 'that's not allowed' and sometimes he would accuse us of hiding. He would say, 'Hoy! Why are you not working? Why are you just sitting there? I will deduct your day's pay!. ... But if you are Visaya, they would pay you better. ${ }^{18}$

The pejorative constructions of Pala'wan labourers had translated to hiring policies that favour migrants and discriminate against Pala'wan smallholders, particularly when their complaints about low wages and food-related debt go unheard. As of early 2016, Mingas had adopted recruitment and employment requirements potentially posing further discrimination against Pala'wan smallholders to work in their plantations. All future and current labourers were requested to supply government identification and birth certificates. As Pala'wan farmers do not have such documents, it leaves their future employment in oil palm plantations in question.

Many migrant farmers have long perceived Pala'wan farmers to be 'unproductive' and 'destructive', and not deserving of prime forested lands. Pala'wan who have continued to practice swidden cultivation are generally viewed as backward kaingineros ${ }^{19}$ incapable of efficiently managing

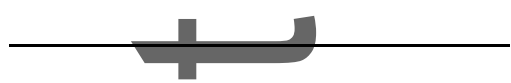

\footnotetext{
${ }^{17}$ Interview, Joselito, Chairman of Mingas, January 2016.

${ }^{18}$ Interview, Amado Venturillo, Pala'wan labourer, January 2016.

${ }^{19}$ Kainginero is a blanket (often derogatory) term used in the Philippines to refer to shifting cultivators. Refer to Montefrio and Dressler (2016) for deeper discussion.
}

This article is protected by copyright. All rights reserved. 
their own lands. Prejudice against Pala'wan swidden cultivators has been reproduced and used in legitimizing the land control dynamics described above. Members and officials of cooperatives have actively persuaded indigenous smallholders to sell or commit their lands to oil palm production, by emphasizing the propensity of the Pala'wan to be unproductive. Likewise, migrant smallholders have been persuaded to participate in oil palm contract farming and to 'develop' their farmlands or swidden plots beyond their current 'unproductive' and 'idle' state. By framing Pala'wan fallow lands and livelihood practices as idle and unproductive, land deals for oil palm development are justified and reinforced as a better alternative to swidden cultivation. Such prejudice clearly mediates and reinforces control over indigenous access to and use of land, income, and traditional foods in the uplands - making Pala'wan farmers more and more dependent on cooperative provisioning. ()

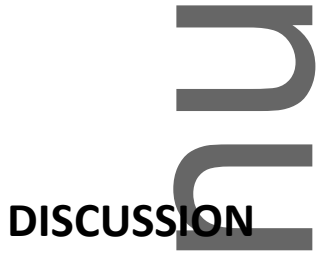

Oil palm development in Palawan reflects a critical juncture in the province's contemporary agrarian political economy. New corporate players - from Sunsol to the LBP — changed the redistributive character of cooperatives to one of capitalist broker with growing financial capital and liabilities that shape land and labour dynamics in ways that negatively impact food security among the indigenous poor. With the entry of oil palm, land prices rose to spur on larger land deals that transformed fallow lands to oil palm plantations and concentrated ownership among migrants and absentee landowners. To the disadyantage of Pala'wan swidden cultivators, land relations became more market-oriented, as renting and sharecropping increasingly constrained the social practice of use and borrowing of kin and neighbours' fallow lands. Oil palm development also spurred widespread participation of smallholders in plantation wage labour. While wages initially supplemented household income needed to purchase food provisions, emerging delays in salary disbursements necessitated that Pala'wan labourers obtain food as credit from cooperative-run variety stores, thereby exposing them to the risks of chronic indebtedness and the need to labour harder to repay food-based credit. These risks are more evident among Pala'wan labourers who curtailed swidden farming for plantation work; others had to negotiate their need to maintain swiddens with the delays in wages, rising debt, and mounting pressures to secure food.

This article is protected by copyright. All rights reserved. 
Closer attention to the socio-political context of credit, debt and labour relations exposes the highly uneven and inequitable character of smallholder experiences of local trajectories of food (in)security - from indentured work to identity politics. Asymmetrical production and exchange relations brought about by unreliable wages resulted in the creation of the bale system, a form of food-for-credit scheme. This scheme is reminiscent of the 'truck system' where labourers' wages are paid in goods (Hilton, 1957), although in the case of cooperatives in Palawan, labourers were given the 'choice' to advance their wage by availing of these goods. Many of the labourers we interviewed, however, felt that out of desperation they had no other choice but to avail of the food credit system. The scheme thus relates to what Gerber $(2013,2014)$ refers to as advances on wages (possibly also in the form of goods), which reflects the kind of loan that allows a creditor to exert labour control over debtors. Not only had this scheme partly pacified labour unrest, it also allowed cooperatives to create conditions of dependence. Given the increasing difficulty of accessing credit elsewhere and the need to continue to labour on plantations, Pala'wan workers have become more dependent on the system because they have no other recourse but to avail themselves of the limited bale food provisions.

Advances on wages also affected the debtor's consumption. While advances of wages allowed Pala'wan labourers to have consistent access to foodstuffs, they were not necessarily consuming food of high nutritional value. The cooperative's bale system set the rules for what sort of foodstuffs labourers could acquire, leading to increased consumption of less nutritious processed foods (e.g. instant noodles, canned goods) high in sodium, sugar and preservatives. While it is unlikely the bale system shifted indigenous food preferences alone, since Pala'wan have long consumed processed goods arising from older patron-client relations in the lowlands, the debtbondage associated with the bale system has reinforced the frequency and quantity of low nutrient foodstuffs aequired by indigenous households incorporated in the oil palm complex in southern Palawan. As Pala wan labour in the plantations, a baseline shift in livelihood activities has taken place, reinforcing risk and uncertainty in accessing traditional foods from forest and field in the uplands. Yet the temporary nature of such labour ensures the potential to reinvest in accessing upland food pathways, despite the prospect of doing so being limited due to rising land scarcity and forest clearing(see Dressler et al., 2016).

Social relations infused with prejudice further inform the labour and livelihood dynamics that mediate food insecurity. Due to the racialized hiring policies, the emerging wage labour dynamics and politics within cooperatives suggest a concentration of employment in favour of migrant smallholders who 'fit' the requirements (i.e. long and regular work hours) of the oil palm production regime (unlike

This article is protected by copyright. All rights reserved. 
Pala'wan farmers who may prefer seasonal labour strategies). While both migrant and indigenous Pala'wan labourers have relied on the bale system, the greater levels of indebtedness and access to processed food among Pala'wan labourers who face a loss of swidden lands to oil palm expansion have placed them in an increasingly precarious position. Declining access to and use of preferred nutritionally diverse food (e.g. varieties of upland rice, tubers, vegetables and fruits and other crops) and NTFPs from constrained swidden lands likely have drawn Pala'wan uplanders associated with the plantation regime toward greater food insecurity. Coupled with the need to earn cash income, less land and declining swidden yields, cooperative officials' prejudiced hiring policies have only exacerbated the material dimensions of food insecurity by reinforcing low self-esteem and sense of shame among indigenous farmers.

We thus emphasize that the ways in which cooperatives mediate livelihoods and food security (to levels of insecurity) reflect and reinforce pre-existing uneven relations of land and labour as oil palm expansion articulates with the local agrarian political economy. Our findings resonate with oil palm contract farming in Sumatra, Indonesia, where farmers also negotiated with cooperatives (dominated by the wealthy) that facilitate the 'division and allocation of land and the contractual, production and credit relations arranged with the plantation core' (McCarthy, 2010: 826). In Palawan, cooperative officials used their power and authority to facilitate local enrolment and land brokering, facilitating the concentration of land among migrants and expansion of oil palm plantations. These land control processes - driven by SunSol and the cooperatives - effectively reduced the availability of fallow land and reinforced those conditions that already pressure swidden agriculture. Our emphasis on the relationality of food (in)security and the role of cooperatives underscores their importance in intensifying uneven social relations of production and exchange in line with how they have unfolded decades prior.

As part of agrarian histories, the roles and functions of cooperatives recently have gone into overdrive by harnessing land, labour and capital more intensively for extended surplus production. Cooperative officials and members have employed pejorative discourses of the 'unproductive' and 'destructive' Pala'wan to delegitimize swidden and persuade smallholders to commit 'idle' lands for oil palm development. Furthermore, cooperatives have set up bale systems and taken advantage of food-for-credit arrangements, primarily as a 'labour fix' intended to sustain their oil palm operations. They also have sustained discrimination against Pala'wan smallholders, thus consequently informing who gets access to the bale system. The confluence of land and labour control, prejudice and credit/debt relations, and other factors, suggests that migrant-dominated cooperatives may likely

This article is protected by copyright. All rights reserved. 
intensify campaigns to secure cheap labour and fallow lands to expand oil palm production effectively aggravating food insecurity.

While rural cooperatives presented here have been reconstituted under the oil palm regime that is, heavily financed, exploitative and increasingly dominated by wealthier migrant farmers - as Brass (200t) reminds us, they too operate in the context of uneven production relations with the oil palm company, SunSol. The two cooperatives we examined were heavily indebted (to LBP and SunSol), absorbing most of the risks and uncertainties associated with the outgrower contract. These conditions required oil palm outgrower cooperatives to appropriate cheap land and labour in order to overcome debt and ensure economies of scale. So while they themselves practised land control by means of exploitative socio-political and economic relations, they also negotiated the unequal production relations and credit/debt terms with the oil palm company. In the end though it is the Pala'wan farmers who were significantly disadvantaged.

Our approach of emphasizing the situated and relational aspects of livelihood and food security trajectories thus illustrates the complexities of food security and agrarian political economy in Palawan. Rather than just describing how cooperatives have constrained access to food, our findings reveal the complex ways in which cooperatives have influenced indigenous farmers' food security pathways by way of mediating social relations associated with land, labour, debt and prejudice. Factoring in the relationality of food security makes explicit the various ways that farmers have negotiated the constraining conditions that cooperatives inform, whether by relying on a relative's land or labour to continue upland farming or balancing labour time between plantation work and swiddening.

\section{CONCLUSION}

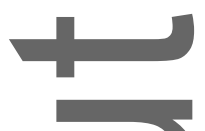

Our analysis focused on how new and reconstituted cooperatives involved in oil palm contract farming mediate local agrarian social relations and political economy to impact upon smallholder food security over time. We did this by integrating a critical agrarian studies lens with a relational, situated food security approach. We provided a multi-faceted and nuanced understanding of indigenous

This article is protected by copyright. All rights reserved. 
smallholders' difficult experiences in accessing and using foods from upland forests and fields in the face of expanding plantation regimes. With an emphasis on the changing nature of social relations of production and exchange, we have shown how migrant-dominated cooperatives have mediated and informed the various trajectories of food (in)securities of indigenous households in uneven agrarian political economies. Understanding these complex food security pathways thus requires a relational

and situated analysis of livelihood change and agrarian relations.

While we argued that cooperatives play an important role in mediating social relations that have livelihood and food security implications, we emphasize that such cooperatives must be analysed as embedded in contract farming arrangements and the oil palm production regime in Palawan more broadly. Given that cooperatives are in fact necessary for contract farming arrangements and plantations to emerge, the added emphasis on cooperatives offers critical depth and nuance in understanding the dynamics of food security in the context of contract farming in plantation regimes. Yet the findings of this article go well beyond the case of oil palm plantations. Indeed, the formation and reconstitution of cooperatives for other agro-industrial production regimes such as rubber and jatropha exists in much of Southeast Asia. More research is therefore needed to examine whether other produetion regimes involving cooperatives reproduce similarly adverse food security pathways for marginalized farmers.

Our findings also pose broader questions on the role of agricultural cooperatives in mediating food security and extractive development in the countryside. Are cooperatives associated with boom crops thus becoming agents of capital accumulation and dispossession? Are they harbingers of food insecurity? Our study suggests cooperatives in oil palm production regimes in Palawan and probably elsewhere strongly inform the local agrarian political economy, its impacts on land, labour and capital, as well as overall levels of food (in)security. We are concerned that cooperatives - once institutions of redistribution and upliftment - are increasingly formed or reconstituted by powerful rural brokers and corporations in support of boom crop production and at the expense of indigenous land rights, livelihood and food security. State and private sector institutions are injecting new finances and capital that have strongly influenced the everyday politics of cooperatives and their objectives of market production and growth through cheap indigenous labour and land. This, we argue, raises critical questions regarding the role of cooperatives in ensuring secure livelihoods and food security in the era of the purported 'green' economy. It remains to be seen what the future relationship between cooperatives and smallholder farmers holds for livelihoods and food security as boom crops expand into and transform frontier lands.

This article is protected by copyright. All rights reserved. 


\section{REFERENCES}

Agarwal, B. (2014) 'Food Sovereignty, Food Security and Democratic Choice: Critical

Contradictions, Difficult Conciliations', Journal of Peasant Studies 41(6): 1247-68.

Appadurai,A. (1996) Modernity at Large. Minneapolis, MN: University of Minnesota Press.

Bartlett, P. (1980) Agricultural Decision Making. Anthropological Contributions to Rural

Development. New York: Academic Press.

Bernstein, H. (1979) 'African Peasantries: A Theoretical Framework', Journal of Peasant Studies $6(4): 421-43$.

Bernstein, H. (2010) Class Dynamics of Agrarian Change. Black Point and Sterling, VA: Kumarian Press.

Berry, S. (1989) 'Access, Control and Use of Resources in African Agriculture', Africa 59(1): 1-5.

Berry, S. (1993) No Condition is Permanent. Madison, WI: University of Wisconsin Press.

Berry, S. (1997) 'Tomatoes, Land and Hearsay: Property and History in Asante in the Time of Structural Adjustment', World Development 25(8): 1225-41.

Bonnin, C. and S. Turner (2012) 'At What Price Rice? Food Security, Livelihood Vulnerability, and State Interventions in Upland Northern Vietnam', Geoforum 43: 95-105.

Borras, S.M. and J.C. Franco (2012) 'Global Land Grabbing and Trajectories of Agrarian Change: A Preliminary Analysis’, Journal of Agrarian Change 12(1): 34-59.

Borras, S.M. and J.C. Franco. (2013) 'Global Land Grabbing and Political Reactions "from Below", Third World Quarterly 34(9): 1723-47.

Borras, S.M., R. Hall, I. Scoones, B. White and W. Wolford (2011) 'Towards a Better Understanding of Global Land Grabbing', Journal of Peasant Studies 38(2): 209-16.

Brass, T. (2007) 'How Agrarian Cooperatives Fail: Lessons from 1970s Peru', Journal of Peasant Studies 34(2): 240-87.

This article is protected by copyright. All rights reserved. 
Carr, E.R. (2006) 'Postmodern Conceptualizations, Modernist Applications: Rethinking the Role of Society in Food Security', Food Policy 31(1): 14-29.

Carr, E.R. (2013) 'Livelihoods as Intimate Government', Third World Quarterly 34(1): 77-108.

Chambers, R. (1995) 'Poverty and Livelihoods: Whose Reality Counts?', Environment and Urbanization 7: 173-204.

Cleaver, F.(2002) 'Reinventing Institutions', The European Journal of Development Research 14(2): $11-30$.

Dalabajan, D.A. (2015) Losing Ancestral Domains to Biofuels Plantations', in J.F. Eder and O.L. Evangelista (eds) Palawan and its Global Connections, pp. 287-305. Manila: Ateneo de Manila Press.

Devereux, S. (2001) ‘Sen's Entitlement Approach: Critiques and Counter-critiques', Oxford Development Studies 29(3): 245-63.

Dressler, W. (2017) 'Contesting Moral Capital in the Economy of Expectations of an Extractive Frontier', Annals of the American Association of Geographers 107(3): 647-65.

Dressler, W. and M. Fabinyi (2011) 'Farmer Gone Fish'n? Swidden Decline and the Rise of Grouper Fishing on Palawan, Philippines', Journal of Agrarian Change 11: 536-55.

Dressler, W. and S. Turner (2008) 'The Persistence of Social Differentiation in the Philippine Uplands', Journal of Development Studies 44(1): 1472-92.

Dressler, W., J. de Koning, M.J.F. Montefrio and J. Firn (2016) 'Land Sharing Not Sparing in the “Green Economy", Geoforum 76: 75-89.

Dressler, W. et al. (2017) 'The Impact of Swidden Decline on Livelihoods and Ecosystem Services in Southeast Asia: A Review of the Evidence from 1990 to 2015', Ambio 46(3): 291-310.

Drèze, J.and A. Sen (1989) Hunger and Public Action. Oxford: Oxford University Press.

Eder, J.F. and O.L. Evangelista (2014) Palawan and its Global Connections. Manila: Ateneo de

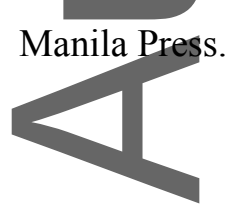

This article is protected by copyright. All rights reserved. 
Ellis, F. (2000) Rural Livelihoods and Diversity in Developing Countries. Oxford: Oxford University Press.

Fabinyi, M.. W.H.Dressler and M.D. Pido (2017) 'Fish, Trade and Food Security: Moving Beyond “Availability” Discourse in Marine Conservation', Human Ecology 45(2): 177-88.

Ferrer, C.M. (1956) 'The Cooperative Movement in the Philippines', Philippine Sociological Review: $33-36$.

Foster, R. (2005) 'Commodity Futures: Labour, Love and Value', Anthropology Today 21(4): 8-12.

Gerber, J-F. (2013) 'The Hidden Consequences of Credit: An Illustration of Rural Indonesia', Development and Change 44(4): 839-60.

Gerber, J-F. (2014) 'The Role of Rural Indebtedness in the Evolution of Capitalism', Journal of Peasant Studies 41(5): 729-47.

Granovetter, M. (1985) 'Economic Action and Social Structure', American Journal of Sociology 91: $481-510$.

Gudeman, S.(1986) Economics as Culture. London: Routledge \& Kegan.

Guinto, M.A. and T. Otahara (1999) 'The Role of Government in the Development of Cooperatives in the Philippines', Review of Agricultural Economics 55: 99-104.

de Haan, L. and A. Zoomers (2005) 'Exploring the Frontier of Livelihoods Research', Development and Change 36(1): 27-47.

Hairong, Y and G. Yiyuan (2013) 'Debating the Rural Cooperative Movement in China', Journal of Peasant Studies 40(6): 955-81

Hall, D. (2011) 'Land Grabs, Land Control, and Southeast Asian Crop booms', Journal of Peasant Studies 38(4): 837-57.

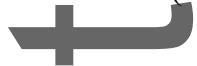

Hall, D., P. Hirsch and T.M. Li (2011) Powers of Exclusion: Land Dilemmas in Southeast Asia. Singapore: National University of Singapore Press.

Hilton, G.W. (1957) 'The British Truck System in the Nineteenth Century', Journal of Political Economy 65(3): 237-56.

This article is protected by copyright. All rights reserved. 
Ingram, J. (2011) ‘A Food Systems Approach to Researching Food Security and its Interactions with Global Environmental Change', Food Security 3(4): 417-31.

Jansen, K. (2015) The Debate on Food Sovereign Theory: Agrarian Capitalism, Dispossession and Agroecology', Journal of Peasant Studies 42(1): 213-32.

Kopytoff, I. (1986) 'The Cultural Biography of Things', in A. Appadurai (ed.) The Social Life of Things, pp. 64-91. Cambridge: Cambridge University Press.

Kumar, V., K.G. Wankhede and H.C. Gena (2015) 'Role of Cooperatives in Improving Livelihood of Farmers on Sustainable Basis', American Journal of Educational Research 3(10): 1258-66.

Larsen, R.K., F. Dimaano and M. Pido (2014) 'The Emerging Oil Palm Agro-industry in Palawan, the Philippines'. SEI Working Paper No. 2014-03. Stockholm: Stockholm Environment Institute.

Li, T.M. (2011) 'Centering Labour in the Land Grab Debate', Journal of Peasant Studies 38(2): 28198

Li, T.M. (2014) Land's End. Durham, NC: Duke University Press.

Li, T.M. (2015) ‘Can There be Food Sovereignty Here?', Journal of Peasant Studies 42(1): 205-11.

MacDonald, C.J. (2007) Uncultural Behavior. Manoa, HI: University of Hawaii Press.

Manalili, N.M. (2003) ‘Linking Farmers to Markets through Cooperatives Vegetables Supply Chain Redesign Options for Kapatagan, Mindanao, Philippines'. Paper presented at the Australian Agrícultural and Resource Economics Society Conference (12-14 February), Perth, Australia.

Maxwell, S. (1996) 'Food Security: A Post-modern Perspective', Food Policy 21(2): 155-70.

Maxwell, S. and M. Smith (1992) 'Household Food Security: A Conceptual Review', in S.

Maxwell and T. Frankenberger (eds), Household Food Security: Concepts, Indicators, Measurements. Rome and New York: IFAD and UNICEF.

McCarthy, J.F. (2010) 'Processes of Inclusion and Adverse Incorporation: Oil Palm and Agrarian Change in Sumatra, Indonesia', Journal of Peasant Studies 37(4): 821-50. McCarthy, J.F. and R.A. Cramb (2009) 'Policy Narratives, Landholder Engagement, and Oil Palm Expansion of the Malaysian and Indonesian Frontiers', The Geographical Journal 175(2): 112-23.

This article is protected by copyright. All rights reserved. 
Montefrio, M.J.F. (2014) 'State versus Indigenous Peoples' Rights: Comparative Analysis of Stable System Parameters, Policy Constraints and the Process of Delegitimation', Journal of Comparative Policy Analysis 16(4): 335-55.

Montefrio, M.J.F. (2017) 'Land Control Dynamics and Social-ecological Transformations in Upland Patawan', Journal of Peasant Studies 44(4): 796-816.

Montefrio, M.J.F.and W. Dressler (2016) 'The Green Economy and Constructions of the "Idle" and "Unproductive" Uplands in the Philippines', World Development 79: 11426.

Montefrio, M.J.F., D.A. Sonnenfeld and V.A. Luzadis (2015) 'Social Construction of the Environment and Smallholder Farmers' Participation in "Low-carbon", Agroindustrial Crop Production Contracts in the Philippines', Ecological Economics 116: $70-77$.

Novellino, D. (2007) 'Cycles of Politics and Cycles of Nature: Permanent Crisis in the Uplands of Palawan', in R. Ellen (ed.) Modern Crises and Traditional Strategies: Local Ecological Knowledge in Island Southeast Asia, pp. 185-219. New York: Berghahn.

Nozawa, K (2011) Oil Palm Production and Cooperatives in the Philippines'. Discussion Paper No. 2011-13. Manila: School of Economics, University of the Philippines.

Osmani, S. (1993) 'The Entitlement Approach to Famine'. Working Paper. Helsinki: WIDER.

Perrault, T. (2005) 'Why Chacras (Swidden Gardens) Persist: Agrobiodiversity, Food Seeurity, and Cultural Identity in the Ecuadorian Amazon', Human Organizations 64(4): $327-39$.

Pinstrup-Andersen, P. (2009) 'Food Security: Definition and Measurement', Food Security 1(1): 5-7.

Reutlinger, S. (1977) 'Malnutrition: A Poverty or a Food Problem?', World Development 5(8): 715-24.

Sam, R.A., A.M. Usop and S. Abubakar-Sam (2013) 'The "Rise and Fall" Experiences of Community Organizations', International Journal of Humanities and Social Science 4): $139-47$.

This article is protected by copyright. All rights reserved. 
Scoones, I. (1998) 'Sustainable Rural Livelihoods: A Framework for Analysis'. IDS Working Paper No. 72. Brighton: Institute of Development Studies.

Scoones, I. (2009) 'Livelihoods Perspectives and Rural Development', Journal of Peasant Studies 36(1): 171-96.

Sen, A. (1981) 'Ingredients of Famine Analysis: Availability and Entitlements', Quarterly Journal of Economics 96(3): 433-64.

Sen, A. (1984) 'The Living Standard', Oxford Economic Papers 36: 74-90.

Sen, A. (1992) Inequality Reexamined. Cambridge, MA: Harvard University Press.

Sen, A. (1999) Development as Freedom. Oxford: Oxford University Press.

Sikor, T. and C Lund (2009) 'Access and Property: A Question of Power and Authority', Development and Change 40(1): 1-22.

Smith, W.(2015) 'Swidden, Climate and Culture: Negotiating "Double Exposure" amongst Indigenous Households on Palawan Island, the Philippines'. Unpublished PhD dissertation, Department of Anthropology, University of Queensland, Australia.

Stewart, F.(1985) Basic Needs in Developing Countries. Baltimore, MD: Johns Hopkins Press.

Warner, K. (1979) ‘Walking on Two Feet: Tagbanuwa Adaptation to Philippine Society’. PhD dissertation, University of California, Santa Barbara, California.

Wilshusen, P.R. (2014) 'Capitalizing Conservation/Development', in B. Büscher, W. Dressler and R. Fletcher (eds) Nature Inc.: Environmental Conservation in the Neoliberal Age, pp. 127-57. Tucson, AZ: University of Arizona Press.

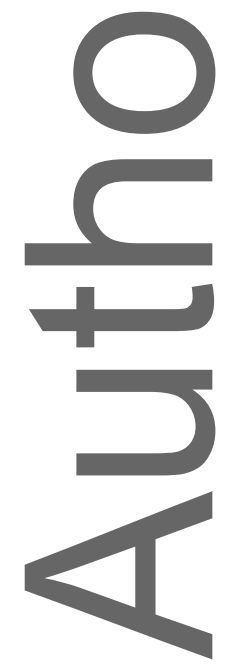

This article is protected by copyright. All rights reserved. 
[Insert author bios here please]

Marvin Joseph F, Montefrio (corresponding author: marvin.montefrio@yale-nus.edu.sg) is an Assistant Professor of Social Science (Environmental Studies) at the Yale-NUS College in Singapore. His main research interest is critical development studies, with particular focus on agriculture and food in Southeast Asia.

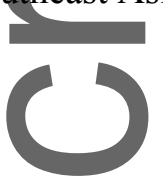

Wolfram H.Dressler (wolfram.dressler@unimelb.edu.au) is an Associate Professor and ARC Future Fellow in the School of Geography, University of Melbourne, Australia. His main research interests are in the political ecologies of conservation and development in Southeast Asia.

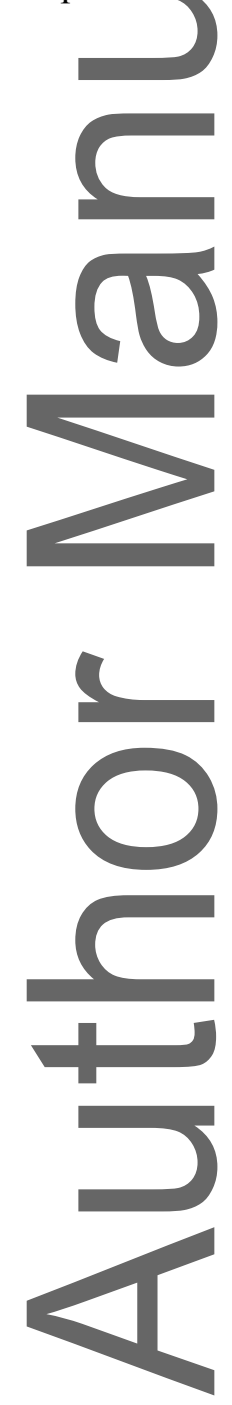

This article is protected by copyright. All rights reserved. 


\section{University Library}

\section{- M M N E R VA A gateway to Melbourne's research publications}

Minerva Access is the Institutional Repository of The University of Melbourne

Author/s:

Dressler, W;Montefrio, M

Title:

Declining Food Security in a Philippine Oil Palm Frontier: The Changing Role of Cooperatives

Date:

2019-09-01

Citation:

Dressler, W. \& Montefrio, M. (2019). Declining Food Security in a Philippine Oil Palm Frontier: The Changing Role of Cooperatives. Development and Change, 50 (5), pp.1342-1372. https://doi.org/10.1111/dech.12443.

Persistent Link:

http://hdl.handle.net/11343/284241 